\title{
Sorption of 2-Chlorophenol from Aqueous Solutions by Functionalized Cross-linked Polymers
}

\author{
Rodrigo Martins Fráguas, Alcino Palermo de Aguiar \\ Departamento de Química, Instituto Militar de Engenharia \\ Angela Cristina Jandrey \\ Souza Cruz S.A.
}

\begin{abstract}
This manuscript describes the synthesis of three polymers based on styrene (STY), divinylbenzene (DVB) and two different vinyl monomers: methyl methacrylate (MMA) and acrylonitrile (AN). The STY-DVB, STY-DVB-MMA and STY-DVB-AN polymers were synthesized employing the aqueous suspension technique. Reaction yields were $73 \%, 81 \%$ and $75 \%$, respectively. They were morphological and chemically characterized using different techniques. The extraction capacity of the polymers was evaluated using 2-chlorophenol. The polymer extraction capacities were evaluated varying contact time the $(1 \mathrm{~h}, 3 \mathrm{~h}$ and $5 \mathrm{~h})$, temperature $\left(30^{\circ} \mathrm{C}, 35^{\circ} \mathrm{C}\right.$ and $\left.40{ }^{\circ} \mathrm{C}\right)$, and $\mathrm{pH}(3,5.6$ and 8$)$. The STY-DVB-AN polymer was the most efficient; it removed around $95 \%$ of the analyte using a contact time $50 \mathrm{~h}$.
\end{abstract}

Keywords: 2-chlorophenol, polymer, extraction.

\section{Introduction}

The growth of the world population has motivated an increase in the demand for food, that has provoked the use of large quantities of herbicides to control different agricultural pests ${ }^{[1]}$. Acidic herbicides, such as 2,4-dichlorophenoxyacetic acid (2,4-D) and 4-chloro-2methylphenoxyacetic acid (MCPA) are widely used to control broad-leaved weeds in plantations ${ }^{[2]}$.

The degradation of 2,4-D and MCPA in soil produces different phenol derivatives, such as: 2-chlorophenol (2-CP), 2-methylphenol, 4-chlorophenol, 2,4-dichlorophenol and 4-chloro-2-methylphenol ${ }^{[3]}$. These derivatives can reach and contaminate subsurface waters polluting the environment. Hence, the extraction of these compounds from water have been investigated ${ }^{[4,5]}$.

These chlorinated organic compounds can be removed from aqueous solution using porous materials such as activated carbons ${ }^{[6]}$ or polymers ${ }^{[7]}$. These latter material have already been employed successfully to extract pollutants from water ${ }^{[8,9]}$.

Cross-linked polymers are of great importance due to their thermal stability and easy synthesis. These polymers may be produced using an aqueous suspension polymerization technique, which provides beads with spherical morphology. This procedure uses an initiator, which by decomposition produces free-radicals that initiate the polymerization and cross-linking reactions ${ }^{[10]}$.

Surface polarity of these polymers can be modified inserting a polar group ${ }^{[11]}$. These functional groups are inserted into the polymeric structure either by functionalized monomer polymerization or by chemical modification of the original polymer ${ }^{[12]}$. Cross-linked polymers have a high specific surface area allowing different interactions $(\pi-\pi$, dipole-dipole or hydrogen bonding) between the aromatic sites and the analyte ${ }^{[13]}$.
These modified polymers are more hydrophilic and are useful for numerous applications ${ }^{[14]}$.

Literature has reported the use of these polymers for organic pollutant extraction ${ }^{[15,16]}$, as well as for the treatment of water produced by the oil industry ${ }^{[17]}$.

The aim of this manuscript was to compare the abilities of three cross-linked polymers to adsorb 2-chlorophenol from an aqueous solution. These polymers were based on styrene and divinylbenzene containing methyl methacrylate or acrylonitrile as the polar monomer.

\section{Experimental}

\section{Materials}

Styrene (STY) was provided by Petroflex; p-divinylbenzene (DVB) (commercial grade $45 \%$, containing a mixture of DVB and $p$-ethylvinylbenzene), acrylonitrile (AN) and methyl methacrylate (MMA) were provided by Nitriflex; 2,2'-Azobis (2-methylbutanenitrile) or Vazo-67 and 2-hydroxyethylcelullose (HEC, Cellosize QP-100MH) were provided by Metacril and Union Carbide, respectively. Monomers and reagents presented commercial grade of purity and were used as received. The reagents gelatin, sodium chloride, propanone, heptane (HEP), toluene (TOL) (Vetec Química Fina Ltd., Brazil) and anisole (ANI) (Merck) were bought as P.A. grade and used as received. Aqueous solutions were prepared using Milli-Q water.

\section{Polymer synthesis}

Aqueous suspension polymerization was carried out in a 1-L, three-necked, round-bottomed flask fitted with a mechanical stirrer, and reflux condenser with a silicon

Corresponding author: Alcino Palermo de Aguiar, Instituto Militar de Engenharia, Departamento de Química, Praça General

Tibúrcio, 80, Praia Vermelha, CEP 22290-270, Rio de Janeiro, RJ, Brazil, e-mail: alcino@ime.eb.br 
oil seal at its top. The aqueous phase (AP) was composed of gelatin and HEC (both at $1 \mathrm{wt} . \%$ in relation to AP) and $\mathrm{NaCl}$ ( 5 wt.\% in relation to AP). The organic phase (OP) was composed of a mixture of monomers with different compositions (total amount $=0.5 \mathrm{~mol}$ ). HEP, TOL or ANI were used as diluents at $200 \%$-v/v in relation to the monomers ${ }^{[10]}$. This percentage was used to favor higher porosity. Vazo-67 was used as an initiator (1 $\mathrm{mol} \%$ in relation to the monomers).

The OP was slowly added to the previously prepared $\mathrm{AP}$, using the ratio $\mathrm{AP} / \mathrm{OP}=4 / 1$. These two phases were maintained under constant stirring $(300 \mathrm{rpm})$ at $25^{\circ} \mathrm{C}$ for $20 \mathrm{~min}$. Finally, the mixture was stirred for $24 \mathrm{~h}$ at $80^{\circ} \mathrm{C}$. Table 1 summarizes the synthesis parameters.

The polymer beads obtained were thoroughly washed with water and propanone in a Soxhlet extractor and dried at $80{ }^{\circ} \mathrm{C}$ overnight. The polymer beads were sieved and the $0.32-0.60 \mathrm{~mm}$ fraction was used in the sorption experiments.

\section{Polymer characterization}

The apparent density (AD) was determined in a graduated cylinder using an adapted procedure of ASTM D1895 ${ }^{[18]}$. The swelling degree (Sd) was determined inserting $3 \mathrm{~mL}$ of synthesized polymer in a $10 \mathrm{~mL}$ graduated cylinder ${ }^{[18]}$. The beads was kept in solvent for $24 \mathrm{~h}$.

The morphological features were observed using an optical microscopy (Nikon, Model SNZ 800). The FTIR spectra (range 4,000-600 $\mathrm{cm}^{-1}$ with a resolution of $4 \mathrm{~cm}^{-1}$ and scan rate of $8 \mathrm{scans} / \mathrm{s}$ ) of the beads were taken in $\mathrm{KBr}$ pellets using a Perkin Elmer Precisely spectrometer. The surface area and pore volume in the dry state were determined by the BET or BJH methods from low-temperature nitrogen adsorption isotherms (ASAP Micromeritics 2010), which were obtained at $77 \mathrm{~K}$ using a high-vacuum volumetric apparatus. The samples were degassed at $100{ }^{\circ} \mathrm{C} / 1 \mathrm{mPa}$ for $3 \mathrm{~h}$.

\section{Adsorption experiments}

The extraction capacity of different polymers was evaluated using batch experiments, which were performed with $0.3 \mathrm{~g}$ of the polymer and $25 \mathrm{~mL}$ of $2-\mathrm{CP}$ $(50 \mathrm{mg} / \mathrm{L})$. The solution was shaken $(120 \mathrm{rpm})$ on an orbital shaker (Cientec CT172) varying the contact time $(1,3$ and $5 \mathrm{~h})$, temperature $\left(30^{\circ} \mathrm{C}, 35^{\circ} \mathrm{C}\right.$ and $\left.40{ }^{\circ} \mathrm{C}\right)$ and $\mathrm{pH}(3,5.6$ and 8). Finally, an aliquot of 2-CP was separated and its concentration was determined by UV/
VIS spectrophotometer (VARIAN, CARY 50). Detection was realized using the wavelength of $274 \mathrm{~nm}$. The 2-CP concentration in solution was determined using an analytical curve $\left(r^{2}=0.9997\right)$.

\section{Results and Discussion}

Three different polymers - C1 (STY/DVB), C2 (MMA/STY/DVB) and C3 (AN/STY/DVB) - were synthesized using the aqueous suspension technique. These reactions presented yields of $73 \%, 81 \%$ and $75 \%$, respectively. All polymers were characterized by FTIR spectra (Figure 1).

All polymer showed absorptions around $1630 \mathrm{~cm}^{-1}$ $(\mathrm{C}=\mathrm{C})$ and $710-750 \mathrm{~cm}^{-1}$ (monosubstituted aromatic ring). $\mathrm{C} 2$ presented absorption bands characteristic of the ester group, such as: $1730 \mathrm{~cm}^{-1}(\mathrm{C}=\mathrm{O})$ and $1150 \mathrm{~cm}^{-1}$ (C-O-C). These results indicated MMA incorporation into the polymer structure. The nitrile group in $\mathrm{C} 3$ was supported by absorption at $2240 \mathrm{~cm}^{-1[19,20]}$.

Swelling degree of polymers (Sd) (Table 2) varied according to the solvent used. This fact indicated that the interaction between solvent and polymeric structure was differentiated $^{[18]}$.

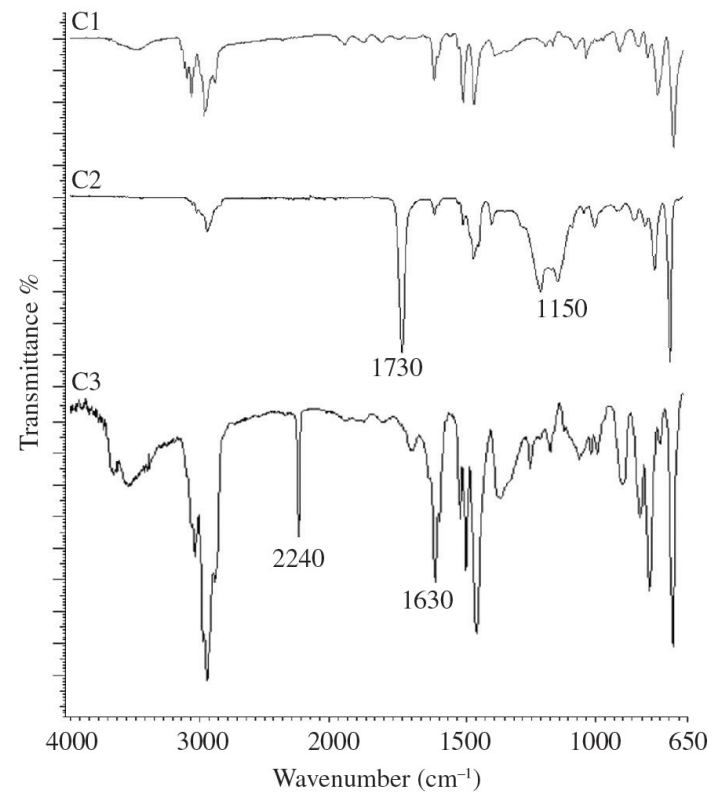

Figure 1. Infrared spectra of synthesized polymers (C1, C2, C3).

Table 1. Synthesis parameters of polymers ${ }^{\mathrm{a}}$.

\begin{tabular}{|c|c|c|c|c|}
\hline Polymer & STY (mol\%) & MMA (mol\%) & AN (mol\%) & $\begin{array}{c}\text { Diluent } \\
\text { system(vol\%) }\end{array}$ \\
\hline \multirow[t]{2}{*}{ C1 - (STY/DVB) } & 80 & - & - & $60 \mathrm{HEP}$ \\
\hline & & & & $40 \mathrm{TOL}$ \\
\hline \multirow[t]{2}{*}{ C2 - (MMA/STY/DVB) } & 40 & 40 & - & $60 \mathrm{HEP}$ \\
\hline & & & & $40 \mathrm{TOL}$ \\
\hline \multirow[t]{2}{*}{ C3 - (AN/STY/DVB) } & 40 & - & 40 & $60 \mathrm{HEP}$ \\
\hline & & & & $40 \mathrm{ANI}$ \\
\hline
\end{tabular}

\footnotetext{
${ }^{\mathrm{a}}$ - all reactions used DVB $(\mathrm{mol} \%)=20$.
} 

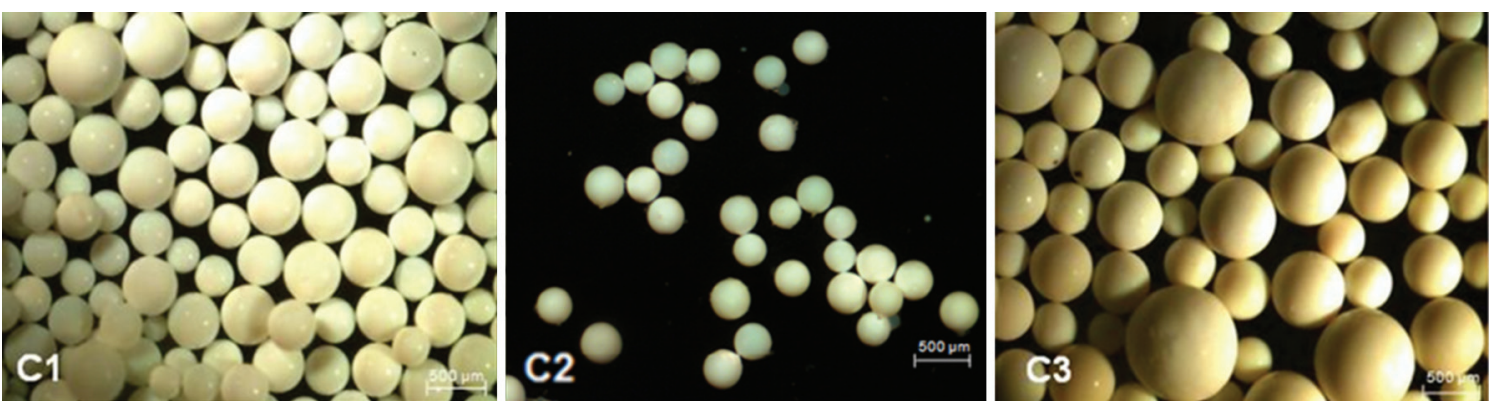

Figure 2. Optical microscopy photomicrograph of synthesized polymers (C1, C2, and C3).

Table 2. Swelling degree of synthesized polymers.

\begin{tabular}{lccc}
\hline \multirow{1}{*}{ Solvent } & \multicolumn{3}{c}{ Swelling percentage } \\
\cline { 2 - 4 } & C1 & C2 & C3 \\
\hline Water & 2 & 4 & 5 \\
Heptane & 26 & 28 & 29 \\
nitrobenzene & 77 & 157 & 130 \\
$o$-dichlorobenzene & 100 & 163 & 154 \\
\hline
\end{tabular}

The swelling degree results using water were not measurable considering an experimental uncertainly of around $10 \%$. The use of heptane produced a poor swelling. Higher percentages were obtained using aromatic solvents (Table 2) that indicated a good affinity between the solvents and polymeric structure ${ }^{[21]}$. The lowest swelling degree obtained with $\mathrm{C} 1$ using aromatic solvents may be related to its lower polarity compared to the others.

All polymers were evaluated using optical microscopy (Figure 2). This technique provided an indication of polymer porosity as a function of different degrees of opacity, such as: transparency, diaphanous and opaque ${ }^{[22]}$.

According to the literature, opaque beads have a structural heterogeneity, which not allows the passage of light through the polymer structure, unlike transparent beads ${ }^{[22,23]}$. This fact is associated to greater refraction of the light passing through the beads. All the polymers reported in this manuscript presented opaque beads with spherical morphology ${ }^{[22,23]}$.

The solubility parameter $(\delta)$ influences the porous nature of polymer. The Hildebrand solubility parameter ${ }^{[24]}$ theory has in many cases proved effective in predicting the physical characteristics of reticulated polymers. Table 3 shows the values for this parameter of the monomers and diluents (pure and mixtures) used in the synthesis.

As the solubility parameter value for synthesized polymers was not found in the literature, the values of the acrylonitrile and methyl methacrylate homopolymers $\left(\delta_{\text {polyAN }}=25.1 \mathrm{MPa}^{1 / 2} ; \delta_{\text {polyMMA }}=18.6 \mathrm{MPa}^{1 / 2}\right)$ were used, as well the STY-DVB copolymer with a cross-linking of $10 \%\left(\delta_{\text {polySTY-DVB }}=15.7 \mathrm{MPa}^{1 / 2}\right)^{[24]}$.

According to the Hildebrand theory ${ }^{[25]}$, the solubility of a polymer in a solvent is favored when this difference $\left(\delta_{1}-\delta_{2}\right)$ is minimized. However, if $\left(\delta_{1}-\delta_{2}\right)>3$ a non solvent character is expected. In this case, the toluene and anisole acted as the solvent diluents and heptane as the non-solvent diluent.
Table 3. Solubility parameters $(\delta)^{[24]}$ of monomers and diluents.

\begin{tabular}{cccc}
\hline Monomer & $\delta\left(\mathbf{M P a}^{1 / 2}\right)^{\mathbf{b}}$ & Diluent & $\delta\left(\mathbf{M P a}^{\mathbf{1 / 2}}\right)^{\mathbf{b}}$ \\
\hline STY & 19.0 & AN & 24.8 \\
DVB & 18.2 & HEP & 15.3 \\
MMA & 18.0 & ANI & 19.4 \\
& & TOL & 18.2 \\
& & HEP/TOL & $16.5^{\mathrm{b}}$ \\
& & HEP/ANI & $16.9^{\mathrm{a}}$ \\
\hline
\end{tabular}

${ }^{\mathrm{a} D i l u e n t s}(\% \mathrm{v} / \mathrm{v})-(60 / 40) ;{ }^{\mathrm{b}} \delta_{\mathrm{dil}}=\sum_{\mathrm{i}} \delta_{\mathrm{i}} \Phi_{\mathrm{i}} ; \delta$ - solubility parameter; $\phi-$ molar fraction.

Table 4. Morphological characteristics of synthesized polymers.

\begin{tabular}{ccccc}
\hline Polymer & $\mathbf{D}_{\mathbf{p}}{ }^{\mathbf{a}}(\mathbf{n m})$ & $\mathbf{d}_{\mathbf{a}}{ }^{\mathbf{b}}\left(\mathbf{g} / \mathbf{c m}^{3}\right)$ & $\mathbf{S}_{\mathbf{a}}{ }^{\mathbf{c}}\left(\mathbf{m}^{2} / \mathbf{g}\right)$ & $\mathbf{V}_{\mathbf{p}}{ }^{\mathbf{d}}\left(\mathbf{c m}^{3} / \mathbf{g}\right)$ \\
\hline $\mathrm{C} 1$ & 27 & 0.40 & 82 & 0.45 \\
$\mathrm{C} 2$ & 83 & 0.39 & 49 & 0.40 \\
$\mathrm{C} 3$ & 74 & 0.42 & 110 & 0.45 \\
\hline
\end{tabular}

${ }^{a}$ Average pore diameter; ${ }^{b}$ apparent density; ${ }^{\text {cspecific surface area; }}$ dpore volume.

Table 3 shows that the solubility parameter $(\delta)$ values for both diluent mixtures were near $\left(16.5 \mathrm{MPa}^{1 / 2}\right.$ and 16.9 $\mathrm{MPa}^{1 / 2}$ ). The difference between the respective solubility parameter of the diluent mixtures and the homopolymer (MMA or AN) were $2.1 \mathrm{MPa}^{1 / 2}$ and 8.2 $\mathrm{MPa}^{1 / 2}$, respectively. Therefore, the formation of a more porous polymer structure could be expected because of the low affinity of the diluent for the polymer, which is formed during the polymerization reaction.

On the other hand, the use of anisole as the diluent aimed to improve the degree of AN incorporation in synthesized polymers when compared to toluene ${ }^{[26]}$. This fact was attributed to the higher anisole dielectric constant $(\varepsilon)$ value $(\varepsilon=4.3)$ compared to toluene $(\varepsilon=2.2)$. Hence, the acrylonitrile loss to the aqueous phase would be reduced ${ }^{[26]}$.

Considering the pore diameter values reported in the literature $^{[27]}$ all synthesized polymers in this work can be classified as mesoporous structures (Table 4).

The lower $\mathrm{C} 1$ pore diameter value was a consequence of the small difference between the solubility parameter of the diluent mixture (16.5 $\left.\mathrm{MPa}^{1 / 2}\right)$ and the copolymer STY-DVB containing a cross-linking degree of $10 \%$ $\left(\delta=15.7 \mathrm{MPa}^{1 / 2}\right)$. In this case, these results indicate a solvent character for the diluents.

Polymers based on MMA (C2) and AN (C3) presented higher pore diameters. This result indicated that the diluents presented a higher non solvating character for C2 
and $\mathrm{C} 3$. This result confirms the expectation for $\mathrm{C} 2$ and C3 porosity according to the difference of the solubility parameters mentioned.

C2 showed the lowest specific area when compared to the others. This fact was justified by the increase of the phase separation, which occurred during the polymerization. On the other hand, C3 that was synthesized in the presence of a polar diluent (ANI) presented a higher specific area. Hence, it is possible to assume that ANI had higher affinity with a polymer compared to toluene. This better affinity can be consequence of a higher dielectric constant of anisole.

The first assays to evaluate the removal of 2-chlorophenol (2-CP) from aqueous solutions by synthesized polymers was performed at $\mathrm{pH} 5.6$ and $30{ }^{\circ} \mathrm{C}$ using batch system and different contact times (Figure 3 ).

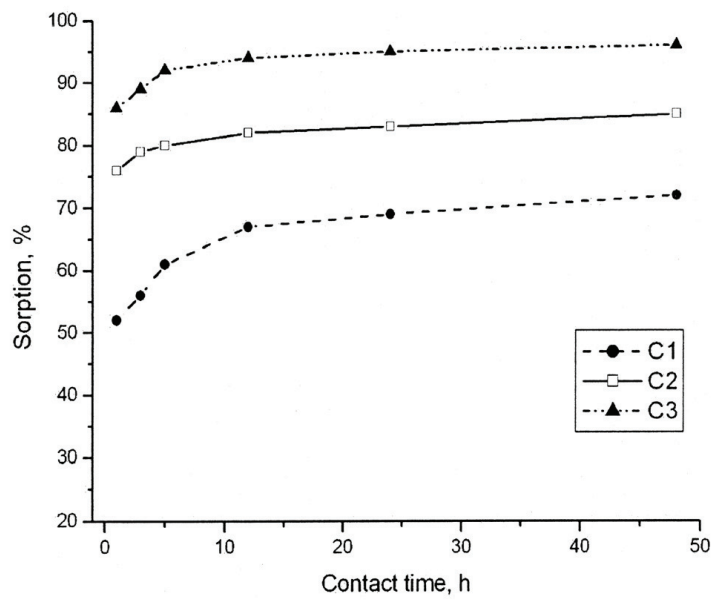

Figure 3. 2-Chlorophenol sorption by $\mathrm{C} 1, \mathrm{C} 2$ and $\mathrm{C} 3$ using different contact times.
The lower sorption presented by $\mathrm{C} 1$ can be associated to its hydrophobicity, which hinders the diffusion process though the polymeric network.

The C3 extraction was more effective followed by $\mathrm{C} 2$ for all contact times. These results can be related to the higher specific surface area and hydrophilicity of C3. The C3 hydrophilicity was influenced by the higher dielectric constant value of AN (33.0) compared with MMA (6.32) $)^{[28]}$

As extraction efficiency after $5 \mathrm{~h}$ was little modified (Figure 3) the next assays investigated the influence of temperature and $\mathrm{pH}$ (Figure 4) using three different contact times (1, 3, and $5 \mathrm{~h})$.

These assays were performed using temperatures of $30{ }^{\circ} \mathrm{C}, 35{ }^{\circ} \mathrm{C}$ and $40{ }^{\circ} \mathrm{C}$ and $\mathrm{pH}$ values of $3,5.6$ and 8. In general, $\mathrm{C} 3$ showed the highest efficiency for all temperatures used. The assays realized at $40{ }^{\circ} \mathrm{C}$ showed a small increase in efficiency (Figure 4), except for C3.

Probably, this result indicates that the $\mathrm{C} 3$ adsorption process occurred predominantly on the surface area. So, the analyte diffusion into porous structure did not have any measurable influence.

Another 2-CP extraction set was performed (Figure 5) using three different $\mathrm{pH}$ values (3, 5.6 and 8). As 2-CP acts as a weak acid $^{[29]}$ in aqueous solutions, the hydrogen ion dissociation is influenced by the solution $\mathrm{pH}$. The assays using different $\mathrm{pH}$ showed that extraction efficiency was $\mathrm{C} 3>\mathrm{C} 2>\mathrm{C} 1$ (Figure 5) for all $\mathrm{pH}$ evaluated.

In these assays, the highest efficiency (92\%) was obtained by $\mathrm{C} 3$ at $\mathrm{pH} 5.6$ using $5 \mathrm{~h}$ of contact time. This result was favored by the higher surface area and the hydrophilicity $^{[30]}$ of $\mathrm{C} 3$ compared to $\mathrm{C} 1$ and $\mathrm{C} 2$, which presented efficiencies of $62 \%$ and $80 \%$, respectively.

The best $\mathrm{C} 3$ result at $\mathrm{pH} 5.6$ was associated to the contributions of the hydrogen bond ${ }^{[30]}$. This interaction
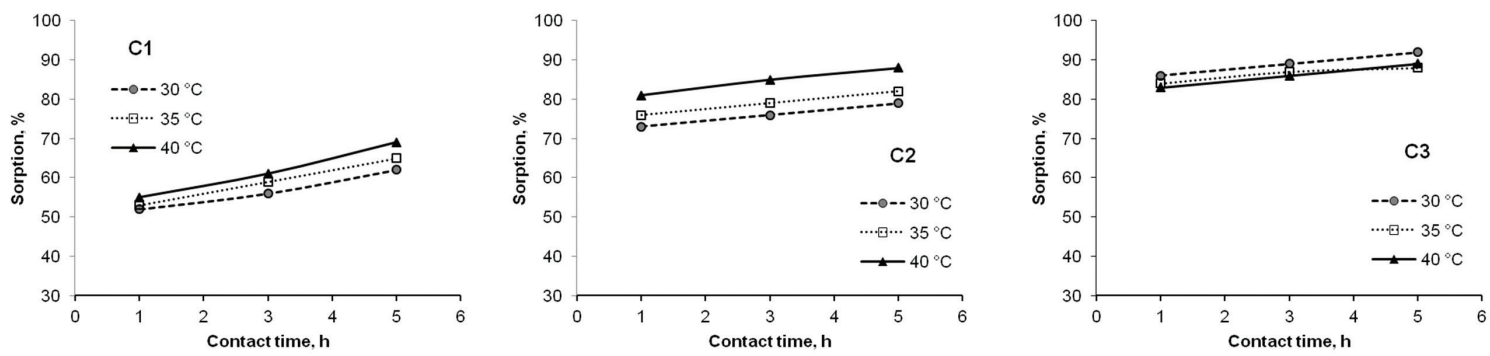

Figure 4. 2-Chlorophenol sorption by polymers $(\mathrm{C} 1, \mathrm{C} 2$ and $\mathrm{C} 3)$ using different temperatures.
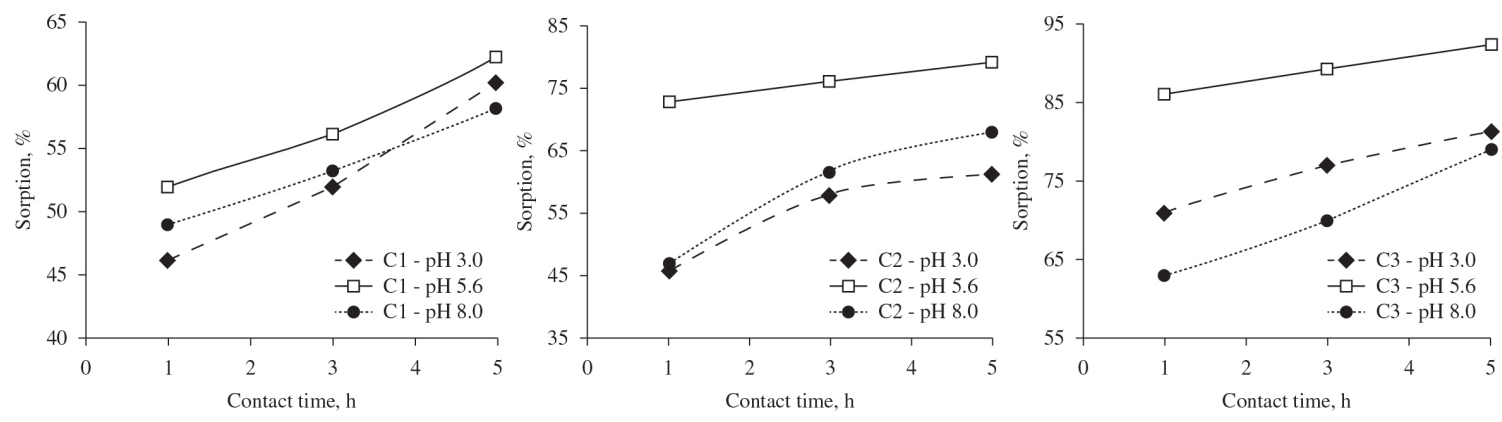

Figure 5. 2-Chlorophenol sorption by polymers $(\mathrm{C} 1, \mathrm{C} 2$ and $\mathrm{C} 3)$ using different $\mathrm{pH}$ values. 
was influenced by the $\mathrm{pH}$ values ( 3 and 8 ). This fact was a consequence of the protonation $(\mathrm{pH} 3)$ of free electrons at the functional group in the polymer, as well the analyte deprotonation ( $\mathrm{pH} 8)$.

The small difference between the analyte pKa (8.2) and basic $\mathrm{pH}$ (8) values favored the presence of two different compounds simultaneously: the phenolate ion and phenol. Under these conditions both intermediates had almost the same concentration. So, $\mathrm{pH} 8$ presented a lower concentration of the phenol derivative capable of forming hydrogen bonds compared to $\mathrm{pH} 5.6^{[31]}$. This can be seen in Figure 5 considering the extraction results of $\mathrm{C} 2$ and $\mathrm{C} 3$ using $\mathrm{pH} 8$ and 5.6.

$\mathrm{C} 2$ and $\mathrm{C} 3$ extraction efficiencies using $\mathrm{pH} 3$ were lower than $\mathrm{pH}$ 5.6. This fact was attributed to the differentiated influence of the functional group in the polymer to form hydrogen bond ${ }^{[31]}$. The lower efficiency to $\mathrm{C} 2$ compared to $\mathrm{C} 3$ at $\mathrm{pH} 3$ was related to more effective ester protonation compared to nitrile. So, C2 had lower quantities of the free functional group to interact with the analyte.

The lower efficiency observed for $\mathrm{C} 1$ was a consequence of its hydrophobic structure. This polymer provides only $\pi-\pi$ interactions ${ }^{[31]}$, so the influence from pH was not measurable.

\section{Conclusions}

The results obtained showed that polymers based on acrylonitrile or methyl methacrylate are potential sorbents capable of removing 2-CP. The surface area and hydrophilicity were important parameters for the sorption efficiency. The best of 2-CP extraction percentage ( 95 \%) was obtained by the $\mathrm{C} 3$ polymer using a contact time $5 \mathrm{~h}$ and $\mathrm{pH}$ 5.6. Temperature range investigated did not influence significantly the extraction process. All polymers showed the best efficiency using $\mathrm{pH}$ 5.6. $\mathrm{C} 1$ polymer presented the lowest efficiency for all $\mathrm{pH}$ used.

\section{Acknowledgements}

The authors thank CAPES and $\mathrm{CNPq}$ for financial support.

\section{References}

1. Bilgili, S. M. \& J. Hazard. - Mater. B, 137, p.157 (2006).

2. Itoh, K.; Kinoshita, M; Morishita, S.; China, M. \& Suyama, K. - FEMS Microbiol. Ecol., 84, p.124 (2013). PMid:23167922. http://dx.doi.org/10.1111/1574-6941.12043

3. D'archivio, A. A.; Fanelli, M.; Mazzeo, P. \& Ruggieri, F. - Talanta, 71, p.25 (2007). PMid:19071262.

4. Yanling, M.; Yingying, W.; Jinhua, L.; Hu, W.; Yangju, D. \& Lingxin, C. - Cent. Eur. J. Chem., 11, p.394 (2013).

5. Yeh, M. K.; Lin, S. L.; Leong, M. I.; Huang, S. D. \& Fuh, M. R. - Anal. Sci., 27, p.49 (2011). PMid:21233560. http:// dx.doi.org/10.2116/analsci.27.49

6. Al-Mubaddel, F. S. - J. Environ. Sci., 22, p.237 (2010).

7. Zeng, X.; Fan, Y.; Wu, G.; Wang, C. \& Shi, R. - Chem. Eng. J., 172, p.341 (2011).

8. Kawabata, N. \& Ohira, K. - Environ. Sci. Technol., 13, p.1396 (1979). http://dx.doi.org/10.1021/es60159a015
9. Wagner, K. \& Schulz, S. J. - Chem. Eng., 46, p.322 (2001).

10. Barbosa, C. C. R.; Cunha, J. W. S. D.; Teixeira, V. G. \& Coutinho, F. M. B. - Polímeros, 8, p. 31 (1998).

11. Fontanals, N.; Marce, R. M.; Galia, M. \& Borrul, F. - J. Polym. Sci.: part A: Polym. Chem., 41, p.1927 (2003). http://dx.doi.org/10.1002/pola.10743

12. Huang, J.; Zha, H.; Jin, X. \& Deng, S. - Chem. Eng. J., 195-196, p.40 (2012). http://dx.doi.org/10.1016/j. cej.2012.04.098

13. Schöbel, M.; Winkenstette, T. M. J. \& Anselment, B. R. - Polym. Sci., 3, p.779 (2012).

14. Zheng, Y.; Pan, L.; Li, Y. G. \& Li, Y. S. - Eur. Polym. J., 44, p.475 (2008). http://dx.doi.org/10.1016/j. eurpolymj.2007.11.017

15. Suchithra, L. V.; Mohamed, A. P. \& Ananthakumar, S. - Chem. Eng. J., 200-202, p.589 (2012). http://dx.doi. org/10.1016/j.cej.2012.06.083

16. Said, H. M.; Sokker, H. H. A. \& El-Hag, A. - Radiat. Phys. Chem., 79, p.534 (2010). http://dx.doi.org/10.1016/j. radphyschem.2009.09.005

17. Filho, D. C. M.; Ramalho, J. B. V. S.; Lucas, G. M. S. \& Lucas, E. F. - Colloids Surf. A: Physicochem. Eng. Aspects, 405, p.73 (2012).

18. Rabelo, D. - "Formação da estrutura porosa em copolímeros à base de estireno e divinilbenzeno", Tese de Doutorado, Universidade Federal do Rio de Janeiro (1993).

19. Fontanals, N.; Marce, R. M.; Galia, M. \& Borrul, F. J. - Cromatogr. A., 1030, p.63 (2004).

20. Lima, K. M. G.; Raimundo, I. M.; Silva, A. S. S. \& Pimentel, M. F. - Quim. Nova., 32, p.1635 (2009). http:// dx.doi.org/10.1590/S0100-40422009000600047

21. Sambe, H.; Hoschina, K. \& Haginaka, J. - J. Cromatogr. A, 1152, p.130 (2007).

22. Cardoso, M. A. \& Lucas, E. F. - Polímeros, 14, p.201 (2004). http://dx.doi.org/10.1590/S0104-14282004000300017

23. Coutinho, F. M. B.; Rezende, S. M. \& Barbosa, C. C. R. - React. Funct. Polym., 49, p. 235 (2001). http://dx.doi. org/10.1016/S1381-5148(01)00079-7

24. Brandup, J.; Immergut, E. H. \& Grulke, E. A. - "Polymer Handbook", John-Wiley, New York (1999).

25. Okay, O. - Prog. Polym. Sci., 25, p.711 (2000). http:// dx.doi.org/10.1016/S0079-6700(00)00015-0

26. Riqueza, E. C.; Santa Maria, L. C.; De Aguiar, M. R. M. P. \& Aguiar, A. P. - Mater. Lett., 58, p.502 (2004). http:// dx.doi.org/10.1016/S0167-577X(03)00534-2

27. Teixeira, V. G.; Coutinho, F. M. B. \& Gomes, A. S. - Quim. Nova., 24, p.808 (2001).

28. Haynes, W. M.; Lide, D. R.; Bruno, J. T. - "CRC Handbook of Chemistry and Physics", CRC press, Taylor \& Francis Group, New York, (2012).

29. Manahan, S. E. - "Environmental Chemistry", CRC Press, Boca Raton, (2005).

30. Pacurariu, C.; Mihoc, G.; Popa, A.; Muntean, S. G. \& Ianos, R. - Chem. Eng. J., 222, p.218 (2013).

31. Ersoz, A.; Denizli, A.; Sener, I.; Atilir, A.; Diltemiz, S. \& Say, R. - Sep. Purif. Technol., 38, p. 173 (2004). 